\title{
Congenital Protein C Deficiency: Family Report from Argentina
}

\section{David Veron $^{1 *}$ | Mariana Varelaํ | Claudio Rosa² | Diego Colimodio ${ }^{2}$ | Mercedes Rojas ${ }^{2}$ | Sofía Juárez Peñalva ${ }^{3}$ | Gabriel Musante ${ }^{4}$ | Manuel Rocca Rivarola ${ }^{5}$}

\section{*Correspondence: David Veron}

Address: ${ }^{1}$ Division of Hematology and Oncology, Department of Pediatrics, Hospital Universitario Austral, Pilar, Argentina; ${ }^{2}$ Central Laboratory, Hospital Universitario Austral, Pilar, Argentina; ${ }^{3}$ Division of Genetics, Department of Pediatrics, Hospital Universitario Austral, Pilar, Argentina; ${ }^{4}$ Division of Neonatology, Department of Pediatrics, Hospital Universitario Austral, Pilar, Argentina; ${ }^{5}$ Department of Pediatrics, Hospital Universitario Austral, Pilar, Argentina

e-mail $\bowtie$ : daveron@cas.austral.edu.ar

Received: 26 September 2020; Accepted: 02 October 2020

Copyright: (C) 2020 Veron D. This is an open-access article distributed under the terms of the Creative Commons Attribution License, which permits unrestricted use, distribution, and reproduction in any medium, provided that the original work is properly cited.

\section{ABSTRACT}

Severe Congenital Protein C Deficiency occurs with an incidence of 1 per 4 million births. Due to the exceptional nature of this entity and the little experience in the literature, we propose to make known some main points of interest of this family.

Keywords: Neonatal Thrombosis, Purpura Fulminans, Protein C

\section{Introduction}

The incidence of asymptomatic Protein C (PC) deficiency has been reported to be between 1 in 200 and 1 in 500 healthy individuals. Based on a carrier rate of $0.2 \%$, a homozygous or compound heterozygous PC deficiency incidence of 1 per 4 million births could be predicted. Due to the exceptional nature of this entity and the little experience in the literature, we propose to make known some main points of interest of this family.

\section{Family Report}

A 2-year-old girl with prenatal diagnosis of a Central Nervous System hemorrhage (Fig. 1 and Fig. 2) was presented to Hematology 2 days before her birth.

Family background: Her 44-year-old father had a spontaneous VTE at the age of 32. Her 40-yearold mother foresaw healthy. The parents are unrelated. The couple had 8 pregnancies and 6 living children, one early miscarriage at week 12 and one fetal loss at week 37 whose autopsy revealed extensive cerebral hemorrhage (Table 1). 


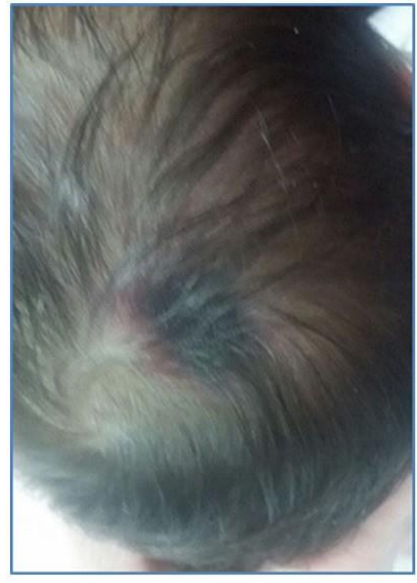

Figure 1

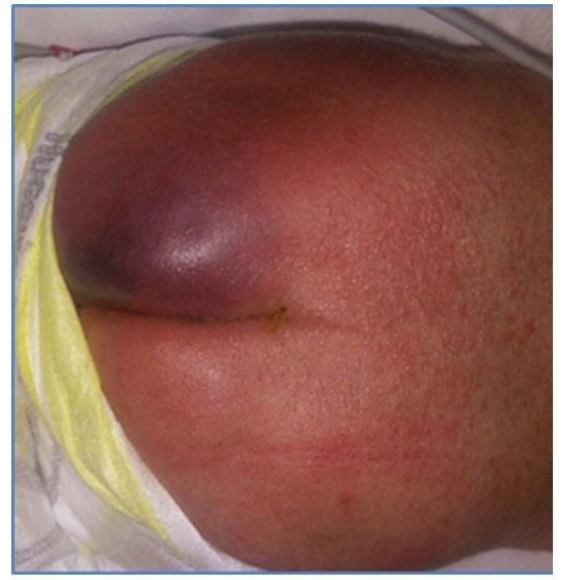

Figure 2

Figure 1 and 2: Skin lesions at first hours of life

Table 1: Laboratory results at diagnosis. Variable pattern of PC levels in a family affected by two mutations. The genetic tests conducted at BAYLOR GENETICS determinate that the mother has pathogenic variant in disease gens related to clinical phenotype and the father has a novel variant of unknown clinical significance in disease genes related to clinical phenotype. The mother has a TYPE I defect, the father has a TYPE II defect and the child has symptoms of severe protein C deficiency and is affected by both mutations. Two siblings have TYPE I defect and one TYPE II. Clearly abnormal results are shown in bold. NR: not realized

\begin{tabular}{|c|c|c|c|c|c|}
\hline Family & $\begin{array}{l}\text { Age at } \\
\text { diagnosis }\end{array}$ & PC defect & $\begin{array}{l}\text { Chromogenic } \\
\text { PC }(\%)\end{array}$ & $\begin{array}{l}\text { Clotting-based } \\
\text { PC (\%) }\end{array}$ & $\begin{array}{l}\text { PC antigen } \\
(\%)\end{array}$ \\
\hline Child & Birth & $\begin{array}{l}\text { Compound heterozygous c.797- } \\
2 \mathrm{~A}>\mathrm{G} \& \text { c. } 172 \mathrm{G}>\mathrm{A}\end{array}$ & 16 & $<1$ & 28 \\
\hline Mother & $40 \mathrm{y}$ & Heterozygous c.797-2A>G & 50 & 53 & 58 \\
\hline Father & $44 \mathrm{y}$ & Heterozygous c. $172 \mathrm{G}>\mathrm{A}$ & 48 & 17 & 79 \\
\hline Sister & $11 \mathrm{y}$ & NR & 74 & 50 & 82 \\
\hline Sister & $9 y$ & Heterozygous c.797-2A>G & 12 & 15 & 31 \\
\hline Sister & $8 y$ & NR & 75 & 45 & 74 \\
\hline Brother & $5 y$ & Heterozygous c.797-2A>G & 13 & 16 & 29 \\
\hline Sister & $3 y$ & Heterozygous c.172G $>A$ & 51 & 30 & 81 \\
\hline $\begin{array}{l}\text { Adult reference } \\
\text { range }\end{array}$ & & & $70-140$ & $70-130$ & $70-140$ \\
\hline
\end{tabular}

The patient's brain injury predicted little chance of survival after birth according to the opinion of the fetal medicine unit. Parents expect to find the cause of this second episode in the family of fetal intracranial bleeding to obtain genetic advice.

Our patient was born in normal childbirth and survived without requiring life support. Cord blood samples were taken at birth for studies of hemostasis and genetic determinations that allowed the diagnosis to be made (Barnes et al., 2002). 
The PC dosages of the patient at birth were: 16\% (chromogenic assay) and $<1 \%$ (clot-based assay). This allowed us to diagnose a SCPCD (TYPE II). The tests conducted at Baylor Genetics revealed compound heterozygous status.

Fresh frozen plasma and fibrinogen concentrate were provided four times a day after birth. At 12 hours of life she developed Purpura Fulminans (PF) and could start to receive PC concentrate (Human) at 5 days of life (Goldenberg and Manco-Johnson, 2008). The initial dose was $80 \mathrm{IU} / \mathrm{kg}$ iv four times a day. The attempts to switch it subcutaneously failed. It was decided to place an implantable catheter for the administration of the concentrate. A bilateral vitreous hemorrhage was diagnosed (Minford et al., 2014; Brouwer et al., 2009; Monagle et al., 2014).

A week after the time of presentation of the PF, the lesions began to resolve. Imaging studies showed no progression of cerebral hemorrhage. After this, the patient started heparinization and after having achieved the desired levels of heparinemia and having sustained them, anticoagulation was started with oral anticoagulants while administering the protein $\mathrm{C}$ concentrate.

Currently receives warfarin and PC concentrate (Human) 80U/kg/day iv through the implantable catheter. Decrease the dose or increase the administration interval led to a rapid increase in D Dimer values and complications with the catheter. Allergic reactions and alloantibody formation are potential complications of any protein replacement therapy but have not been described in patients to date.

The protein $\mathrm{C}$ dosages of the mother were: 50\% (chromogenic assay), 53\% (clot-based assay). A TYPE I deficiency was diagnosed. A heterozygous c.797-2A $>$ G pathogenic variant in the PROC gene was detected in the mother. This defect is cause of thrombophilia due to protein C deficiency. Additionally, a heterozygous c.172G>A (p.E58K) variant of unknown significance (VUS) in the PROC gene was also detected in the father. The data indicate that the two changes in the PROC gene are in trans configuration (compound heterozygous) in the patient. The protein $\mathrm{C}$ dosages of the father were: $48 \%$ (chromogenic assay), 17\% (clot-based assay). A TYPE II deficiency was diagnosed.

Once the genetic defects in the PROC gene were identified, we were able to perform the sequencing directed in the siblings' samples. This was done at the Austral University Hospital.

The three asymptomatic siblings have a moderately severe PC deficiency, 2 of them inherited the maternal genetic defect while a sister inherited the paternal genetic defect (Table 1). After discussing the best management for these children, it was agreed to observe and provide them prophylaxis with PC concentrate when necessary. 


\section{Main Point of Interest}

The index case presented with an antenatal intracranial bleed in late pregnancy. A previous sibling died in utero in late pregnancy with an intracranial bleed, almost certainly due to undiagnosed SCPCD.

Although SCPCD is a serious thrombotic disorder, it can present with intracranial bleeding usually in late pregnancy. When a baby dies of intracranial bleeding in utero, it is important to consider SCPCD as a possible cause.

It is also important to consider SCPD in the differential diagnosis of neonatal intracranial hemorrhage. Cases of SCPCD can certainly present with cerebral infarction/hemorrhage before purpura fulminans.

The history of a previous sibling dying of intracranial bleeding in utero together with the father's history of early VTE could ideally have pointed to the possibility of both parents being heterozygotes for protein $\mathrm{C}$ deficiency with subsequent checking their protein $\mathrm{C}$ levels and genetic mutations. Subsequently antenatal diagnosis by chorionic villus biopsy would have shown that the patient was a compound heterozygote. An early (34 weeks) elective caesarean section could have possibly avoided the intracranial thrombosis with resulting infarction/hemorrhage.

The genetic test conducted revealed in the patient's father and in one asymptomatic sister that the VUS defect detected in the PROC gene (Heterozygous c.172G>A) results here in a TYPE II deficiency in these two cases.

Regarding the behavior adopted with the asymptomatic brothers with moderate deficiency, it helped to know that anticoagulation is not usually required when plasma PC concentrations are maintained above a nadir of $50 \%$ around a surgery and above $20 \%$ under basal conditions. This concept has allowed invasive surgical procedures to be carried out with a low risk of major hemorrhage thanks to the contribution of PC concentrate.

\section{Challenge}

A International Registry of patients with PF as well as international cooperation is necessary (International Epidemiological Study of Neonatal Purpura Fulminans - Web-based registry created under the auspices of the International Society of Thrombosis and Hemostasis and hosted by The Hospital for Sick Children, Toronto, Canada: https://www.isth.org/page/RegistriesDatabases). 


\section{Abbreviations}

\section{SCPCD : Severe Congenital Protein C Deficiency}

\section{PC: Protein C}

PF: Purpura Fulminans

VTE: Venous thromboembolism

VUS: Variant of unknown significance

\section{Conflict of Interest}

All authors declare no conflict of interest Photographs were taken with the parental consent.

\section{Acknowledgments}

We want to thank Dr. Adrian Minford (UK) for his invaluable support to help this family.

\section{References}

Barnes C, Newall F, Higgins S, Carden S, Monagle P. Perinatal management of patients at high risk of homozygous protein C deficiency. Thromb Haemost 2002; 88: 370-371.

Brouwer J-LP, Lijfering WM, ten Kate MK, Kluin-Nelemans HC, Veeger NJ, van der Meer J. High long-term absolute risk of recurrent venous thromboembolism in patients with hereditary deficiencies of protein S, protein $\mathrm{C}$ or antithrombin. Thromb Haemost 2009; 102: 93-99.

Goldenberg N and Manco-Johnson M. Protein C deficiency. Haemophilia 2008; 14: 1214-1221.

Minford A, Behnisch W, Brons P, David M, Gomez Gomez N, Hertfelder HJ, Kruempel A, Kurnik K, Mathias M, Molines Honrubia A, Monagle P, Morgan M, Nowak-Göttl U, Olivieri M. Subcutaneous protein C concentrate in the management of severe protein C deficiency--experience from 12 centres. Br J Haematol 2014; 164: 414-421.

Monagle K, Ignjatovic V, Hardikar W, Newall F, Monagle P. Long-term follow-up of homozygote protein C deficiency after multimodal therapy. J Pediatr Hematol Oncol 2014; 36: 452-455. 